\title{
Clinical Features and Diagnosis of Spontaneous Intracerebral Hemorrhage
}

\author{
Shayan Alijanpour ${ }^{1}$, Alijan Ahmadi Ahangar ${ }^{2 *}$, and Mostafa Mostafazdeh Bora ${ }^{3}$ \\ ${ }^{1}$ Isfahan University of Medical Science, Iran \\ ${ }^{2}$ Babol University of Medical Sciences, Iran \\ ${ }^{3}$ North Khorasan University of Medical Sciences, Iran
}

*Corresponding author: Alijan Ahmadi Ahangar, Mobility Impairment Research Center, Health Research Institute, Babol University of Medical Sciences. Babol, Iran.

Received Date: January 16, 2019

Published Date: January 31, 2019

\begin{abstract}
Background: Intracerebral hemorrhage (ICH) is the second most common type of stroke, trailing only ischemic stroke in frequency. There are many underlying pathological conditions associated with ICH; hypertension, amyloid angiopathy, ruptured saccular aneurysm, and vascular malformation account for the majority of cases. Initial goals of treatment include preventing hemorrhage extension, as well as the prevention and management of elevated intracranial pressure along with other neurologic and medical complications.

Summary of review: Data were obtained from 21 studies conducted between 2000 to 2018 with title of Spontaneous intracerebral hemorrhage research articles were included in this review that we review clinical features and diagnosis of Spontaneous intracerebral hemorrhage.
\end{abstract}

Conclusion: Hypertensive vasculopathy is the most common etiology of spontaneous intracerebral hemorrhage. Major risk factors for spontaneous ICH are hypertension, older age, the presence of cerebral amyloid angiopathy.

Keywords: Intracerebral hemorrhage; Stroke; Hypertension

\section{Introduction}

Stroke is the second leading cause of death worldwide [1,2]. The pathogenesis, epidemiology, clinical features, and diagnosis of spontaneous (atraumatic) ICH will be reviewed here. Thirteen percent of strokes are hemorrhagic, the prevalence of subarachnoid hemorrhage $(\mathrm{SAH})$ are 3 percent and intracerebral hemorrhage (ICH) are 10 percent [3].

\section{Etiology}

Hypertensive vasculopathy is the most common etiology of spontaneous ICH. Cerebral amyloid angiopathy and vascular malformations are the most common cause of nontraumatic lobar ICH in the elderly and children respectively. These disorders are discussed elsewhere in appropriate topic reviews. Hypertensive ICH- Hypertensive hemorrhages occur in the territory of penetrator arteries often at 90 degree angles with the parent vessel. These small penetrating arteries may be particularly susceptible to the effects of hypertension because of pressure of the much larger parent vessel directly [4].
The blood vessels with hypertensive hemorrhage usually are similar to hypertensive occlusive disease and diabetic vasculopathy, which cause lacunar strokes. These vessels supply the pons and midbrain (penetrators off the basilar artery), thalamus (thalamostriate penetrators off the P1 and P2 segments of the posterior cerebral arteries), and putamen and caudate (lenticulostriate penetrators off the M1 segment of the middle cerebral artery). Hypertensive vasculopathy is also believed to play a role in the development of white matter disease, which may explain the finding of an association between white matter disease and risk of ICH [5].

The combination of Pathologic examination of the blood vessels in chronic hypertension disease and ICH disorder create hypertensive hemorrhage theory. The development of penetrator vessels in intimal hyperplasia with hyalinosis can create focal necrosis and broken in the wall of the vessel. These microscopic "pseudoaneurysms" with subclinical leaks of blood may be relatively 
common. When the clotting system is unable in controlling vessel wall problem create massive hemorrhage.

Cerebral amyloid angiopathy - Cerebral amyloid angiopathy (CAA), although usually asymptomatic, is an important cause of primary lobar ICH in elderly people. CAA create weakens the structure of the vessel walls and bleeding because of the deposition of congophilic material in small to medium-sized blood vessels of the brain and leptomeninges. Manifestation of CAA is spontaneous lobar hemorrhage. The common location of CAA-related ICH is in the putamen, thalamus, and pons.

Other causes - Other causes of nontraumatic ICH include [6]:

a. Hemorrhagic infarction (including cerebral venous thrombosis)

b. Septic embolism, mycotic aneurysm

c. Brain tumor

d. Bleeding disorders, liver disease, thrombolytic therapy

e. Central nervous system infection (eg, herpes simplex encephalitis)

f. Moyamoya disease

g. Vasculitis

h. Cerebral hyperperfusion syndrome

i. Reversible cerebral vasoconstriction syndromes (RCVS)

j. Drugs (cocaine, amphetamines) [7]

\section{Pathogenesis}

Cerebral microbleeds - Neuroimaging data suggest that microscopic pseudoaneurysm formation with subclinical leaks of blood is relatively common in patients with spontaneous ICH [8]. These microbleeds or microhemorrhages may be a marker of bleeding-prone microangiopathy due to hyalinosis (chronic hypertension) or amyloid deposition and infective endocarditis. Microbleeds may be more common in antithrombotic consumption patients $[9,10]$

Mechanisms of brain injury - brain injury mechanism in ICH, including primary direct mechanical injury to brain parenchyma. Pathologic examination indicates 22 of 33 older adults (ages 71 to 105 years) that occur the expanding clot and cytotoxic perilesional edema. In fact, clot volume and perilesional edema increase intracranial pressure (ICP) and cerebral herniation and reduced cerebral perfusion [11]. Secondary brain injury after the initial hemorrhage is an important contributing process with uncertain mechanism. Postcontrast enhancement may be noted in the perihematomal area on CT and MRI, representing blood-brain barrier disruption [12]

Hemorrhage enlargement - Serial CT scans in patients with hypertensive hemorrhage have shown that the hemorrhage enlarges in the first few hours after presentation in a subset of patients. In most cases, the bulk of hemorrhage expansion occurs in the first three hours after onset of ICH. In a prospective series of 103 patients with ICH, significant hemorrhage growth $(a>33$ percent volume increase) occurred in 38 percent of patients over the first 24 hours [13].

\section{Epidmiogy}

Nontraumatic intracerebral hemorrhage (ICH) is the cause of 9 to 27 percent of all strokes globally. The prevalence of ICH in Babol was $28.4 \%$. while in study conducted in Babol in 2018, the prevalence of ICH decline to $22 \%$. In other study, the prevalence of Hemorrhagic stroke was $16 \%[1,14,15]$.

\section{Risk Factors}

Major risk factors for spontaneous ICH are hypertension, older age, the presence of cerebral amyloid angiopathy (a primary cause of lobar ICH), and the use of anticoagulant therapy. Hypertension hypertension is the most important risk factor for the development of ICH. Hypertension more than doubles the risk of ICH $[16,19]$. The finding of study of Ahmadi Ahangar et al in Iran in 2018 indicates Hypertension was most frequent stroke risk factor especially in Intracerebral Hemorrhage and male patients. Of 61 case of ICH, $37.7 \%$ cases involved Hypertension [14]. Also, in prognosis of ICH patients were influential [20]. Also, other study conducted by AhmadiAhangar indicates that the frequent of Hypertension was higher in hemorrhagic stroke significantly [1].

Antithrombotic therapy - Anticoagulant therapy is associated with an increased risk of ICH, whereas the risk of ICH with antiplatelet therapy is uncertain but likely minimal.

1) Anticoagulants -Anticoagulation with warfarin increases the risk of ICH two- to five-fold, depending upon the intensity of anticoagulation. This is discussed separately $[18,21]$.

2) In addition to an increased risk of $\mathrm{ICH}$, retrospective evidence suggests that warfarin therapy with an international normalized ratio (INR) $>3$ is a risk factor for larger initial hemorrhage volume as well as poorer outcomes after ICH.

3) Antiplatelets - There is probably a small absolute increased risk of primary ICH associated with the use of aspirin or antiplatelet agents, based on meta-analyses of randomized, controlled trials, although other case-control studies have not found an increased risk [22]

4) Other risk factors - other risk factors for ICH include high alcohol intake, black ethnicity, lower cholesterol and LDL levels, and genetic variation. Also, other study indicates that Zinc Serum Level ia associated with stroke. The cause of it is uncertain. Babol stroke patients are prone to increased zinc serumlevel as a new parameter $[3,23]$. Also, of stroke patients included in this study $66 \%$ of them had hyponatremia and the frequency of hyponatremia in ischemic and hemorrhagic was $82 \%$ and $63 \%$, respectively. Hyponatremia can effect on severity of the stroke [2]. Also, patient with Diabetete have bad prognosis in ICH and was common in ICH patient [24,25].

5) High alcohol intake is associated with an approximately three-fold increased risk of ICH

6) Black ethnicity is associated with an increased risk of ICH that is age-related. Findings from a surveillance study and a 
prospective cohort have found that the risk factors of race and age appear to interact, such that young (45 to 60 years) blacks have a higher risk of ICH than whites, but this increased risk declines with increasing age [26].

7) Smoking: in study conducted by Ahmadi Ahangar et al in Iran, the aim of study Clinical Patterns and Early Prognosis of Stroke in Babol indicate that High smoking was seen in Intracerebral Hemorrhage. Of 61 cases with ICH, 31.14\% have ICH and in smoking individual was higher ICH significantly [14]. In other study, smoking was risk factor for ICH [25].

8) In other study the frequent of smoking in hemorrhagic patient was higher than ischemic stroke significantly.

9) Lower cholesterol and lower LDL cholesterol are associated with an increased ICH risk. A systematic review and meta-analysis of 23 prospective studies found an inverse relationship between total and LDL-cholesterol and the risk of ICH . However, most systematic reviews and meta-analyses have found that treatment with statins does not increase the risk of primary ICH or to negatively impact prognosis [27]. Also, in other study cholesterol in died ICH patients was lower than survivor ICH patient significantly [20].

\section{Clinical Presentation}

The signs and symptoms of hypertensive ICH vary according to the location and size of the hemorrhage.

Onset and progression - the most cases take place during routine activity. The neurologic symptoms and signs usually increase gradually over minutes or a few hours, in contrast to brain embolism and subarachnoid hemorrhage, where the neurologic symptoms and signs are often maximal at onset. However, some patients with ICH are obtunded or comatose when first discovered or upon arrival to the emergency department.

Headache, vomiting, and a decreased level of consciousness develop in sufficiently large hemorrhage. Headache and vomiting occur in approximately one-half of patients with intracerebral hemorrhage (ICH). Headache may be due to traction on meningeal pain fibers, increased intracranial pressure (ICP), or blood in the cerebrospinal fluid (CSF); it is most common with cerebellar and lobar hemorrhages. These symptoms are absent with small hemorrhages; the clinical presentation in this setting is that of a gradually progressing stroke. Patients may complain of a stiff neck and have meningismus on physical examination, if there is intraventricular blood.

Stupor or coma in ICH is an ominous sign. The only exception is patients with thalamic hemorrhage, in whom involvement of the reticular activating system is the cause of stupor rather than diffuse brain injury; these patients may recover after blood is reabsorbed. Putaminal hemorrhage - Spread of hemorrhage into the putamen most commonly occurs along white matter fiber tracts, causing hemiplegia, hemisensory loss, homonymous hemianopsia, gaze palsy, stupor, and coma. Internal capsule hemorrhage - Small hemorrhages restricted to the internal capsule may cause mild dysarthria, contralateral hemiparesis and sensory deficit [28].
Cerebellar hemorrhage - Cerebellar hemorrhage usually originates in the dentate nucleus, extends into the hemisphere and fourth ventricle, and possibly into the pontine tegmentum. These bleeds cause an inability to walk due to imbalance, vomiting, headache, neck stiffness, gaze palsy, and facial weakness without hemiparesis. Cerebellar hemorrhage is a crucial diagnosis to make since these patients frequently deteriorate and require surgery.

Thalamic hemorrhage - a thalamic hemorrhage may extend in a transverse direction to the posterior limb of the internal capsule, downward to put pressure on the tectum of the midbrain or may rupture into the third ventricle. Symptoms include hemiparesis, hemisensory loss, and occasionally transient homonymous hemianopsia. There may also be an upgaze palsy with miotic pupils that are unreactive, peering at the tip of the nose, skewed, or "wrong way eyes" toward the weak side (in contrast to hemispheric cortical injury in which the eyes are deviated away from the hemiparesis). Aphasia may occur if the bleed affects the dominant hemisphere, while neglect may develop if the bleed affects the nondominant hemisphere. Also, mortality rate in Thalamic hemorrhage was higher significantly [29] Lobar hemorrhage - Lobar hemorrhages vary in their neurologic signs depending upon location. They most often affect the parietal and occipital lobes. These bleeds are associated with a higher incidence of seizures. Occipital hemorrhages frequently present with a very dense contralateral homonymous hemianopsia. Hemorrhages in the frontal region will bring about a contralateral plague or paresis of the leg with relative sparing of the arm.

Pontine hemorrhage - Pontine hemorrhage is characterized by a medial hemorrhage that extends into the base of the pons. These often lead to deep coma over the first few minutes following the hemorrhage, probably due to disruption of the reticular activating system. The motor examination is marked by total paralysis. The pupils are pinpoint and react to a strong light source. Horizontal eye movements are absent, and there may be ocular bobbing, facial palsy, deafness, and dysarthria when the patient is awake (Table 1).

\section{Complications}

\section{Rebleeding}

According to studies, the survivor of $1.3-7.4 \%$ and up to $18.8 \%$ of ICH patient experience recurrence within a years and five years respeactly $[30,31]$. In the other study primary ICH recurrence occurred in $9.8 \%$ of cases [21]. Seizures - Seizures in the first days after ICH occur approximately 15 percent of patients; they are more common in lobar hemorrhages (affecting cortical tissue) than in deep or cerebellar ICH [32].

Cardiac abnormalities - Cardiac abnormalities are commonly associated with spontaneous ICH. The most frequently associated electrocardiographic (ECG) changes are prolonged QT interval and ST-T wave changes. These changes may reflect catecholamineinduced cardiac ischemia, which is most likely due to a centrally mediated release of excess catecholamines caused by increased intracranial pressure or autonomic disturbance [33].

Evaluation and Diagnosis Ich is a neurologic and medical emergency because it is associated with a high risk of ongoing 
bleeding, progressive neurologic deterioration, permanent disability, and death. The acute evaluation of patients with suspected stroke, including issues related to the history, physical examination, airway and breathing, and immediate laboratory studies, is discussed in detail separately. Neuroimaging with brain CT or MRI is mandatory to confirm the diagnosis of ICH and to exclude ischemic stroke and stroke mimics as possible causes. Once acute ICH is confirmed by imaging, the etiology must be determined based upon clinical and imaging features. The main considerations are patient age, associated risk factors (primarily hypertension), and ICH location (lobar versus nonlabor) (Table 1).

Table 1:

\begin{tabular}{|c|c|c|c|c|c|c|}
\hline $\begin{array}{c}\text { Authors } \\
\text { (Year) }\end{array}$ & $\begin{array}{l}\text { Country, } \\
\text { Region }\end{array}$ & $\begin{array}{l}\text { Study } \\
\text { Design }\end{array}$ & Sample & Prevalence of Ich & Sites of Hematoma Or Size & Associated Factors \\
\hline $\begin{array}{c}\text { Bhatia et al. } \\
\text { [17] }\end{array}$ & India & $\begin{array}{l}\text { Prospec- } \\
\text { tive obser- } \\
\text { vational } \\
\text { study }\end{array}$ & $\begin{array}{l}\text { Patients of } \\
\text { spontaneous ICH } \\
\text { admitted under } \\
\text { stroke services } \\
\text { of the neurology } \\
\text { department at All } \\
\text { India Institute of } \\
\text { Medical Sciences }\end{array}$ & $\begin{array}{l}214 \text { caseICH(- } \\
\text { 193supratentorial } \\
\text { and } 21 \text { infraten- } \\
\text { torial) }\end{array}$ & $\begin{array}{c}\text { ganglionic }(70.6 \%) \text {, thalamic } \\
(16.8 \%), \text { lobar }(4.2 \%), \text { brainstem } \\
(7 \%) \text { and cerebellar }(1.4 \%)\end{array}$ & $\begin{array}{l}\text { Between Survived (144 } \\
\text { case)and died(70 case):Hy- } \\
\text { pertension, Diabetes, } \\
\text { Dyslipidemia, Smoking, Past } \\
\text { stroke was higher in died } \\
\text { but no significant. Indepen- } \\
\text { dent predictors of mortality: } \\
\text { Ventilatory requirement, } \\
\text { Intraventricular extension } \\
\text { of Hemorrhage, Baseline } \\
\text { hematoma volume, GCS* } \leq 8\end{array}$ \\
\hline HU et al. [18] & China & $\begin{array}{l}\text { Cohort } \\
\text { study }\end{array}$ & $\begin{array}{l}266 \text { cases of ICH } \\
\text { in hospital of } \\
\text { Hangzhou City }\end{array}$ & 266 cases of ICH & $\begin{array}{l}\text { basal ganglia(34.2\%), thalamus } \\
(8.3 \%) \text {, cerebellum ( } 6.8 \%), \text { ventri- } \\
\text { cles(1.5\%), and brainstem (1.1\%), } \\
\text { temporal ( } 9.8 \% \text { of all ICH cases), } \\
\text { occipital ( } 5.6 \%) \text {,frontal ( } 7.1 \%) \text {, } \\
\text { and parietal (3.0\%) lobes, and } \\
11.7 \% \text { of all ICH patients exhibited } \\
\text { hemorrhages in multiple lobe }\end{array}$ & $\begin{array}{l}\text { Hypertension as major } \\
\text { riskfactor: in } 79.1 \% \text { of basal } \\
\text { ganglia, } 68.2 \% \text { of thalamic, } \\
\text { and } 41.7 \% \text { of multisite ICH } \\
\text { cases, but in only a minority } \\
\text { of cerebellar (22.2\%) and } \\
\text { lobar (20.2\%) ICH cases. } \\
\text { Hypertension (33.3\%), } \\
\text { renal disease (33.3\%), and } \\
\text { cerebral infarction (33.3\%) } \\
\text { were the three most com- } \\
\text { mon possible factors leading } \\
\text { to brainstem hemorrhage. } \\
\text { Warfarin-associated ICH } \\
\text { cases and those during } \\
\text { intracranial operations all } \\
\text { occurred in the cerebral } \\
\text { lobes (100\%) The cerebral } \\
\text { lobes were also the most } \\
\text { common sites for ICHs } \\
\text { associated with metastatic } \\
\text { tumor (75.0\% of tumor } \\
\text { cases had hemorrhage } \\
\text { located in one or more } \\
\text { lobes), traffic accidents } \\
\text { (69.2\%), moyamoya disease } \\
\text { (66.7\%), cerebrovascular } \\
\text { malformation (61.5\%), } \\
\text { thrombopenia (including } \\
\text { leukemia, } 57.1 \%), \text { and ce- } \\
\text { rebral aneurysms (53.8\%). } \\
\text { In contrast, the majority } \\
\text { of ICHs in patients with } \\
\text { hypertension, renal disease, } \\
\text { or cerebral infarction were } \\
\text { located in the basal ganglia } \\
(59.2 \%, 50.0 \% \text {, or 50.0\%, } \\
\text { respectively), while ICHs } \\
\text { associated with cirrhosis } \\
\text { were mainly located in the } \\
\text { cerebellum (40.0\%) or at } \\
\text { multiple sites ( } 40.0 \%\end{array}$ \\
\hline $\begin{array}{c}\text { Kim et al. } \\
\text { [21] }\end{array}$ & $\begin{array}{l}\text { South } \\
\text { Korea }\end{array}$ & $\begin{array}{l}\text { A prospec- } \\
\text { tive cohort } \\
\text { study }\end{array}$ & $\begin{array}{l}2384 \text { patients } \\
\text { diagnosed with su- } \\
\text { pratentorial P-ICH } \\
\text { and hypertension } \\
\text { in the stroke unit } \\
\text { of a single-cen- } \\
\text { ter( } 1317 \text { cases } \\
\text { defined AHDs) }\end{array}$ & $\begin{array}{l}\text { P-ICH recurrence } \\
\text { occurred in } 129 \\
(9.8 \%)\end{array}$ & $\begin{array}{l}\text { Location of 1st P-ICH:11.6\% lobar } \\
\text { 8.5\% non lobar } \\
\text { IVH with 1st P-ICH: } 9.5 \%\end{array}$ & $\begin{array}{c}\geq 70 \text { years Lobar ICH } \\
\text { Uncontrolled Hypertension } \\
\text { Anti-coagulant } \\
\text { Medication Ischemic heart } \\
\text { disease Ischemic stroke }\end{array}$ \\
\hline
\end{tabular}




\begin{tabular}{|c|c|c|c|c|c|c|}
\hline $\begin{array}{l}\text { Hasan et al. } \\
\text { [20] }\end{array}$ & Iraq & $\begin{array}{l}\text { A prospec- } \\
\text { tive study }\end{array}$ & $\begin{array}{l}\text { of } 70 \text { consecutive } \\
\text { patients with } \\
\text { spontaneous } \\
\text { intracerebral } \\
\text { hemorrhage } \\
\text { (48 men and } 22 \\
\text { women)the use of } \\
\text { Modified Rankin } \\
\text { scale (mRS) }\end{array}$ & $\begin{array}{l}\text { Of } 70 \text { cases with } \\
\text { ICH } \\
\text { (24 (38\%) died in } \\
\text { the hospital) }\end{array}$ & $\begin{array}{c}\leq 35 \mathrm{~cm}: 5.7 \% \\
35-70 \mathrm{~cm}: 38.6 \% \\
>70 \mathrm{~cm}: 45.7 \%\end{array}$ & $\begin{array}{c}\text { Significant Higher MRs } \\
\text { with:Male sex, Age } \geq 65 \text {, } \\
\text { Size of hematoma }(\mathrm{cm} 3) \\
>70, \text { Temperature }\left({ }^{\circ} \mathrm{C}\right)>37.2 \text {, } \\
\text { Respiratory Rate }(\text { breath/ } \\
\text { min) }>15 \text { Serum cholesterol } \\
(\mathrm{mg} / \mathrm{dl}) \leq 200 \text {, between not } \\
\text { Died and Died: significant } \\
\text { higher Mean Arterial } \\
\text { Pressure, Temperature, } \\
\text { Respiratory, Rate, Size of } \\
\text { Hematoma, and age in died } \\
\text { patient Significant lower } \mathrm{S} \text {. } \\
\text { Cholesterol in died patient }\end{array}$ \\
\hline $\begin{array}{l}\text { Almutawa et } \\
\text { al. [29] }\end{array}$ & $\begin{array}{l}\text { Kingdom } \\
\text { of Bahrain }\end{array}$ & $\begin{array}{l}\text { Retrospec- } \\
\text { tive }\end{array}$ & $\begin{array}{l}\text { Personal, clinical } \\
\text { and neuroimaging } \\
\text { characteristics of } \\
54 \text { patients with } \\
\text { SICH admitted } \\
\text { from January } 2009 \\
\text { to December } 2011\end{array}$ & $\begin{array}{l}54 \text { patients with } \\
\text { SICH }\end{array}$ & $\begin{array}{c}\text { Lobar( 25.9\%),BG \& Th(44.4\%), } \\
\text { Brain Stem(11.1\%), Cerebel- } \\
\text { lum(7.4\%) } \\
\text { Multiple(7.4\%),Isolated } \\
\text { IVH(3.7\%) }\end{array}$ & $\begin{array}{c}\text { Significant higher mortality } \\
\text { rate: } \\
\text { BG \& Th ICH } \\
\text { ICH Volume (8) }>60 \\
\text { Having Intraventricular } \\
\text { extension }\end{array}$ \\
\hline $\begin{array}{l}\text { Koivunen et } \\
\text { al. [24] }\end{array}$ & Finland & $\begin{array}{l}\text { a cohort } \\
\text { study }\end{array}$ & $\begin{array}{l}\text { Patients includ- } \\
\text { ed had their } \\
\text { non-traumatic } \\
\text { first-ever, ICH be- } \\
\text { tween the ages of } \\
16 \text { and } 49 \text { treated } \\
\text { in HUCH, between } \\
1 \text { January } 2000 \\
\text { and } 31 \text { March } \\
2010\end{array}$ & Of 131 cases & - & $\begin{array}{l}\text { Significant higher mortality } \\
\text { rate: } \\
\text { Male gender } \\
\text { Diabetes } \\
\text { Intraventricular extension }\end{array}$ \\
\hline $\begin{array}{c}\text { Vatsal et al. } \\
\text { [19] }\end{array}$ & Lucknow & $\begin{array}{l}\text { a } \\
\text { cross-sec- } \\
\text { tion } \\
\text { obser- } \\
\text { vational } \\
\text { study }\end{array}$ & $\begin{array}{l}75 \text { patients of } \\
\text { ASICH belonging } \\
\text { to } \\
\text { different age } \\
\text { groups and both } \\
\text { sexes }\end{array}$ & $\begin{array}{l}75 \text { patients of } \\
\text { ASICH }\end{array}$ & $\begin{array}{c}\text { Lobar haematoma(29.3\%),Tha- } \\
\text { lamic/putaminal haemato- } \\
\text { ma(41.3\%), Cerebellar hae- } \\
\text { matoma(2.7\%),Brain stem } \\
\text { haematoma(2.7\%),intraventicular } \\
\text { haematoma(13.3\%),Subarachnoid } \\
\text { haematoma(26.7\%) }\end{array}$ & $\begin{array}{c}\text { Hypertension(46.7\%) } \\
\text { Aneurysm(17.3\%) } \\
\text { AVM(6.7\%) } \\
\text { Tumour(1.3\%) } \\
\text { Unexplained(28\%) }\end{array}$ \\
\hline $\begin{array}{l}\text { Celikbilek et } \\
\text { al. [25] }\end{array}$ & Turkey & $\begin{array}{l}\text { A retro- } \\
\text { spective } \\
\text { study }\end{array}$ & $\begin{array}{l}106 \text { patients (60 } \\
\text { male, } 46 \text { female) } \\
\text { who were diag- } \\
\text { nosed with spon- } \\
\text { taneous ICH in } \\
\text { Baskent University } \\
\text { Hospital }\end{array}$ & $\begin{array}{l}106 \text { patient with } \\
\text { spontaneous ICH }\end{array}$ & --- & $\begin{array}{c}\text { Risk factor:Smoking } \\
\text { 17.9\%,Alcohol 7.5\%,DM } \\
23.6 \% \\
\text { Hyperlipidemia } 11.3 \%, \\
\text { Uncontrolled Hypertension } \\
50.9 \% \\
\text { Higher mortality rate, Over } \\
65 \text { years,Bleeding volume } \\
\text { Ventricular extension of } \\
\text { Hemorrhage Midline shift }\end{array}$ \\
\hline $\begin{array}{l}\text { Ahangar et } \\
\text { al. [1] }\end{array}$ & Iran & $\begin{array}{l}\text { cross-sec- } \\
\text { tional }\end{array}$ & $\begin{array}{l}\text { All patients } \\
\text { presented to the } \\
\text { neurology center } \\
\text { at Ayatollah } \\
\text { Rouhani Hospita }\end{array}$ & $\begin{array}{l}\text { A total of } 230 \text { pa- } \\
\text { tients with stroke } \\
\text { Hemorrhagic } \\
\text { Stroke: } 15.65 \%\end{array}$ & ----- & $\begin{array}{c}\text { Significant riskfactor for } \\
\text { ICH: } \\
\text { Hypertension } \\
\text { Smoking } \\
\text { Opioid addiction }\end{array}$ \\
\hline $\begin{array}{l}\text { Ahangar et } \\
\text { al. [14] }\end{array}$ & Iran & $\begin{array}{l}\text { cross-sec- } \\
\text { tional }\end{array}$ & $\begin{array}{l}\text { All patients } \\
\text { presented to the } \\
\text { neurology center } \\
\text { at Ayatollah } \\
\text { Rouhani Hospita }\end{array}$ & $\begin{array}{c}\text { Hemorrhagic } \\
36(16 \%): \\
\text { Intracerebral } 22 \\
\quad(61 \%) \\
\text { Subarachnoid } 14 \\
(39 \%)\end{array}$ & ------- & $\begin{array}{c}\text { hypertension was statistical- } \\
\text { ly significant and increased } \\
\text { in intracerebral subtype }(25 \\
\text { patients }(70 \%) \text { Intracerebral } \\
\text { vs. } 11 \text { patients }(30 \%) \text { Sub- } \\
\text { arachnoid, }(\mathrm{P}=0.01) \text {. Also, } \\
\text { the difference in Cardiac } \\
\text { Disease }(\mathrm{p}<0.0001) \text {, Dia- } \\
\text { betes Mellitus }(\mathrm{p}<0.001) \text {, } \\
\text { Smoking ( } \mathrm{p}<0.001), \text { Opioid } \\
\text { Addiction }(0.04) \text { was sta- } \\
\text { tistically significant and } \\
\text { increased in Intracerebral } \\
\text { patients }\end{array}$ \\
\hline
\end{tabular}

Recommended laboratory tests for patients with ICH include

1. Complete blood count, electrolytes, blood urea nitrogen, creatinine, and glucose
2. Prothrombin time (with INR) and activated partial thromboplastin time for all patients; thrombin clotting time for patients taking direct oral anticoagulants (and/or icariin 
clotting time where available for patients known or suspected to be taking direct thrombin inhibitors)

3. Cardiac-specific troponin

4. Toxicology screen to detect cocaine and other sympathomimetic drugs

5. Urinalysis and urine culture

6. Pregnancy test in a woman of childbearing age [34].

BRAIN IMAGING - Both CT and MRI are considered first-choice imaging options for the emergency diagnosis and assessment of ICH

Head CT - Noncontrast head CT is the study most widely used to evaluate for the presence of acute ICH, which is evident almost immediately. CT can define the size and location of the hemorrhage. It also provides information about extension into the ventricular system, the presence of surrounding edema, and shifts in brain contents (herniation). Hyperacute blood will appear hyperdense unless the patient is severely anemic, in which case it might appear isodense. Over weeks, the blood will become isodense and may have a ring enhancement appearance. Chronically, the blood is hypodense.

\section{Brain MRI}

Hemorrhage appearance - Hyperacute parenchymal hemorrhage can be accurately detected using MRI with T2-sensitive pulse sequences such as gradient echo (GRE). These sequences are highly sensitive to the nonuniform static magnetic fields produced by paramagnetic molecules such as deoxyhemoglobin. This property of paramagnetic molecules is termed the magnetic susceptibility effect; it results in rapid dephasing of proton spins causing signal loss (darkening or hypointensity) that is best seen in T2*-weighted images.

Predicting hemorrhage expansion - The spot sign and swirl sign are imaging markers that suggest an increased risk for hemorrhage expansion.

A. Spot sign - The spot sign describes the appearance of small focal or multifocal areas of contrast enhancement within a hemorrhage on CTA source images. The spot sign has been linked to hemorrhage expansion and poor outcomes in several studies [35]

B. Swirl sign - The swirl sign describes the appearance on nonenhanced CT of rounded, linear, or irregular regions that are hypodense or isodense (compared with normal brain parenchyma) within the region of hyperdensity that represents the hemorrhage. Limited data suggest that the swirl sign is associated with hemorrhage expansion, poor outcome, and increased mortality [36]

\section{Summary and Recommendation}

Hypertensive vasculopathy is the most common etiology of spontaneous intracerebral hemorrhage (ICH). Cerebral amyloid angiopathy is the most common cause of nontraumatic lobar ICH in the elderly, while vascular malformations are the most common cause of ICH in children. Additional causes include tumors, coagulopathies, and others.

I. Major risk factors for spontaneous ICH are hypertension, older age, the presence of cerebral amyloid angiopathy (a primary cause of lobar ICH), and the use of anticoagulant therapy.

II. The signs and symptoms of ICH vary according to the location and size of the hemorrhage. Patients typically present with an acute onset of a focal neurologic deficit that corresponds to the part of the brain affected. The neurologic symptoms and signs usually increase gradually over minutes or a few hours. Headache, vomiting, and a decreased level of consciousness develop if the hemorrhage becomes sufficiently large. Seizures complicate 15 percent of patients, particularly if the hemorrhage is more superficial than deep.

III. Computed tomography angiography (CTA) or magnetic resonance angiography [37] of the intracranial circulation are useful screening tests for vascular malformations, aneurysms, and moyamoya vessels. Contrast-enhanced MRI along with MRA and magnetic resonance venography (MRV) are also useful to evaluate for underlying structural lesions, including cerebral vein thrombosis.

\section{Acknowledgement}

None.

\section{Conflict of Interest}

No conflict of interest.

\section{References}

1. Ahangar AA, Saadat P, Heidari B, Taheri ST, Alijanpour S, et al. (2018) Sex difference in types and distribution of risk factors in ischemic and hemorrhagic stroke. International Journal of Stroke 13(1): 83-86.

2. Ahangar AA, Bazuiar B, Saadat P, Hosseinzadeh H, Mortazavinezhad R, et al. (2017) Hyponatremia and Disability, Prevalence and Prognosis in Babol Stroke Patients. Advances in Biosciences \& Clinical Medicine 11.

3. Ahmadi Ahangar A, Saadat P, Niroomand S, Alijanpour S, Sohrabnezhad $\mathrm{R}$, et al. (2018) Increased Zinc Serum Level: New Clues in Babol Stroke Patients, Northern Iran. Stroke research and treatment.

4. Meretoja A, Strbian D, Putaala J, Curtze S, Haapaniemi E, et al. (2012) SMASH-U: a proposal for etiologic classification of intracerebral hemorrhage. Stroke 43(10): 2592-2597.

5. Folsom AR, Yatsuya H, Mosley TH, Psaty BM, Longstreth W, et al. (2012) Risk of intraparenchymal hemorrhage with magnetic resonance imaging-defined leukoaraiosis and brain infarcts. Annals of neurology 71(4): 552-559.

6. van Asch CJ, Velthuis BK, Greving JP, van Laar PJ, Rinkel GJ, et al. (2013) External validation of the secondary intracerebral hemorrhage score in The Netherlands. Stroke 44(10): 2904-2906.

7. Martin-Schild S, Albright KC, Hallevi H, Barreto AD, Philip M, et al. (2010) Intracerebral hemorrhage in cocaine users. Stroke 41(4): 680-684.

8. Cheng A-L, Batool S, McCreary CR, Lauzon M, Frayne R, et al. (2013) Susceptibility-weighted imaging is more reliable than $\mathrm{T} 2 *$-weighted gradient-recalled echo MRI for detecting microbleeds. Stroke 44(10): 2782-2786.

9. Orken DN, Kenangil G, Uysal E, Forta H (2009) Cerebral microbleeds in ischemic stroke patients on warfarin treatment. Stroke 40(11): 363836340 .

10. Fisher M, French S, Ji P, Kim RC (2010) Cerebral microbleeds in the elderly: a pathological analysis. Stroke 41(12): 2782-2785. 
11. Xu B-N, Yabuki A, Mishina H, Miyazaki M, Maeda M, et al. (1993) Pathophysiology of brain swelling after acute experimental brain compression and decompression. Neurosurgery 32(2): 289-296.

12. Kidwell C, Burgess R, Menon R, Warach S, Latour L, et al. (2011) Hyperacute injury marker (HARM) in primary hemorrhage A distinct form of CNS barrier disruption. Neurology 77(19): 1725-1728.

13. Mayer SA, Brun NC, Begtrup K, Broderick J, Davis S, et al. (2008) Efficacy and safety of recombinant activated factor VII for acute intracerebral hemorrhage. New England Journal of Medicine 358(20): 2127-2137.

14. Ahmadi A, Saadat P, Alijanpour S, Tahereh Taheri S (2018) Clinical Patterns and Early Prognosis of Stroke in Babol, Northern Iran. Journal of biomedical science and engineering 4: 30-35.

15. Ahangar AA, Vaghefi SBA, Ramaezani M (2005) Epidemiological evaluation of stroke in Babol, northern Iran (2001-2003). European neurology 54(2): 93-97.

16. McKinney JS, Kostis WJ (2012) Statin therapy and the risk of intracerebral hemorrhage: a meta-analysis of 31 randomized controlled trials. Stroke 43(8): 2149-2156.

17. Bhatia R, Singh H, Singh S, Padma MV, Prasad K, et al. (2013) A prospective study of in-hospital mortality and discharge outcome in spontaneous intracerebral hemorrhage. Neurology India 61(3): 244-248.

18. Hu Yz, Wang Jw, Luo By (2013) Epidemiological and clinica characteristics of 266 cases of intracerebral hemorrhage in Hangzhou, China. Journal of Zhejiang University Science B 14(6): 496-504.

19. Dk Vatsal D, Rajeev Kainth D, Mazhar Husain D (2017) Acute Spontaneous Intra Cranial Haemorrhage- A Clinical Study of 75 Cases at Lucknow. IOSR Journal of Dental and Medical Sciences 16: 09-12.

20. Al Mousawi ZN, Al Tameemi KM, Haji GF (2012) Predictors of Outcome for Spontaneous Intracerebral Hemorrhage in Iraqi Stroke Patients. Iraqi Academic Scientific Journal 11(4): 503-509.

21. Kim YZ, Park YH, Song YG, Kim KH (2013) Clinical analysis of factors predisposing the recurrence of primary intracerebral hemorrhage in patients taking anti-hypertensive drugs: A prospective cohort study. Clinical neurology and neurosurgery 115(5): 578-586.

22. He J, Whelton PK, Vu B, Klag MJ (1998) Aspirin and risk of hemorrhagic stroke: a meta-analysis of randomized controlled trials. Jama 280(22): 1930-1935.

23. AhmadiAhangar A, Saadat P, Arab F, Firozejahi A, Biani MA, et al. (2017) Zinc serum level can be a risk factor in babol stroke patients? Advances in Biosciences \& Clinical Medicine 10.

24. Koivunen RJ, Tatlisumak T, Satopää J, Niemelä M, Putaala J, et al. (2015) Intracerebral hemorrhage at young age: long-term prognosis. European journal of neurology 22(7): 1029-1037.
25. Celikbilek A, Goksel BK, Zararsiz G, Benli S (2013) Spontaneous intracerebral hemorrhage: A retrospective study of risk factors and outcome in a Turkish population. Journal of neurosciences in rural practice 4(3): 271-277.

26. Sturgeon JD, Folsom AR, Longstreth W, Shahar E, Rosamond WD, et al. (2007) Risk factors for intracerebral hemorrhage in a pooled prospective study. Stroke 38(10): 2718-2725

27. Wang X, Dong Y, Qi X, Huang C, Hou L, et al. (2013) Cholesterol levels and risk of hemorrhagic stroke: a systematic review and meta-analysis. Stroke 44(7): 1833-1839.

28. Chung CS, Caplan LR, Yamamoto Y, Chang HM, Lee SJ, et al. (2000) Striatocapsular haemorrhage. Brain 123(9): 1850-1862.

29. Almutawa E, Shahda A, Albalooshi M (2012) Spontaneous Intracerebral Haemorrhage (SICH): Factors Associated with in hospital Mortality. Bahrain Medical Bulletin 34(2): 1-6.

30. Poon MTC, Fonville AF, Salman RAS (2014) Long-term prognosis after intracerebral haemorrhage: systematic review and meta-analysis. J Neurol Neurosurg Psychiatry 85(6): 660-667.

31. Schmidt LB, Goertz S, Wohlfahrt J, Melbye M, Munch TN, et al. (2016) Recurrent intracerebral hemorrhage: associations with comorbidities and medicine with antithrombotic effects. PloS one 11(11): e0166223.

32. Kuramatsu JB, Sauer R, Mauer C, Lücking H, Kloska SP, et al. (2010) Correlation of age and haematoma volume in patients with spontaneous lobar intracerebral haemorrhage. Journal of Neurology, Neurosurgery \& Psychiatry 82(2):144-149.

33. Pinnamaneni S, Aronow WS, Frishman WH (2017) Neurocardiac injury after cerebral and subarachnoid hemorrhages. Cardiology in review 25(2): 89-95.

34. Hemphill III JC, Greenberg SM, Anderson CS, Becker K, Bendok BR, et al. (2015) Guidelines for the management of spontaneous intracerebral hemorrhage: a guideline for healthcare professionals from the American Heart Association/American Stroke Association. Stroke 46(7): 20322060

35. Wada R, Aviv RI, Fox AJ, Sahlas DJ, Gladstone DJ, et al. (2007) CT angiography "spot sign" predicts hematoma expansion in acute intracerebral hemorrhage. Stroke 38(4): 1257-1262.

36. Rodriguez Torres A, Murphy M, Kourkoulis C, Schwab K, Ayres AM, et al. (2018) Hypertension and intracerebral hemorrhage recurrence among white, black, and Hispanic individuals. Neurology 91(1): e37-e44.

37. Abid KA, Vail A, Patel HC, King AT, Tyrrell PJ, et al. (2013) Which factors influence decisions to transfer and treat patients with acute intracerebral haemorrhage and which are associated with prognosis? A retrospective cohort study. BMJ open 3(12): e003684. 